\section{Ameliorating Effect of Emblica Officinalis on Lipid Profile of Endosulfan Induced Mice}

\author{
Sanjeev Kumar Jha* and Dilip Kumar Paul \\ Department of Zoology, Patna University, Patna, Bihar, India
}

\begin{abstract}
In the recent times wide use of agrochemicals in agricultural practice has caused severe health hazards to humans while their side effects have damaged the environment also. Endosulfan is an organochlorine insecticide effective against a wide range of pests of cereals, coffee, cotton, fruits, oilseeds, potato, tea and vegetables. Moreover, it is easily absorbed by the stomach, lungs and skin and exposure through any route can be hazardous. In the present study, Endosulfan was administered orally at the dose of $3 \mathrm{mg} / \mathrm{Kg}$ body weight to Swiss albino mice for 4 weeks. Upon 4 weeks Endosulfan pretreated mice group, Emblica officinalis (Amla fruit) at the dose of $100 \mathrm{mg} / \mathrm{Kg} \mathrm{b.w}$ was orally administered for 4 weeks to these groups to observe the ameliorative effect. Mice were sacrificed at each interval and their blood were collected for biochemical assay especially lipid profile. The lipid profile study showed inclination in the total cholesterol level, cholesterol (LDL) level and triglycerides level while declination in cholesterol (HDL) level after Endosulfan exposure. But upon Emblica officinalis (Amla) treatment to the endosulfan treated group showed significant declination in the total cholesterol level, cholesterol (LDL) level and triglycerides level while inclination in cholesterol (HDL) level. Thus, from the above study it can be concluded that although the entrance of these hazardous pesticide (Endosulfan) into our body cannot be stopped but by the use of these medicinal plant extracts as potent antidote can solve the problem at much extent, normalizing the physiology of the body and maintaining the cellular integrity and normal functioning of the system.
\end{abstract}

Keywords: Amelioration; Emblica officinalis; Endosulfan; Hyperlipidaemia

*Corresponding author: Sanjeev Kumar Jha, Department of Zoology, Patna University, Patna, Bihar, India, Tel: +91 8538915010; Email: sjha258@gmail.com

Citation: Jha SK, Paul DK (2020) Ameliorating Effect of Emblica Officinalis on Lipid Profile of Endosulfan Induced Mice. J Toxicol Cur Res 4: 020.

Received: June 30, 2020; Accepted: August 26, 2020; Published: September 02, 2020

Copyright: @ $2020 \mathrm{Jha}$ SK, et al. This is an open-access article distributed unde the terms of the Creative Commons Attribution License, which permits unrestricted use, distribution, and reproduction in any medium, provided the original author and source are credited.

\section{Introduction}

Pests are responsible for the loss of one third of worlds agriculture production every year. In India approximately, agricultural products of more than 60 billion annually are destroyed by pests. Every year this problem is increased by the appearance of new pests and diseases [1]. Pesticides are group of chemicals mainly designed for the destruction of pests but besides killing pests it also affects the heath of non-target organisms. only a small percentage $(0.3 \%)$ of applied pesticides goes into the target pest while $99.7 \%$ go somewhere else into the environment [2]. Endosulfan is an organochlorine insecticide effective against a wide range of pests of cereals, coffee, cotton, fruits, oilseeds, potato, tea and vegetables. Moreover, it is easily absorbed by the stomach, lungs and skin and exposure through any route can be hazardous. Commercially produced endosulfan consists of two isomers $\alpha$ endosulfan and $\beta$ endosulfan. Both these forms have been proved to be genotoxic to human gonads $[3,4]$.

Due to the high persistence and bioaccumulation potential, the Stockholm Convention has classified endosulfan as environmental hazards and banned the use of many of them. Pesticide safety is classified by the World Health Organization (WHO) according to the results of $\mathrm{LD}_{50}$ tests, which document the amount of a chemical required to kill $50 \%$ of a population of laboratory animals. Under this system, endosulfan is currently classified as Class II moderately hazardous to human health. However, the United States' Environmental Protection Agency (EPA) rates endosulfan as Category $\mathrm{Ib}$ - highly hazardous. $\mathrm{LD}_{50}$ data for endosulfan are equivocal, with some published results indicating that the chemical should be in the WHO's Class Ib, according to the organization's own criteria [5]. Evidence of the threats to human health posed by endosulfan is abundant, and the chemical has been banned outright or severely restricted in a number of countries as a result. Independent of $\mathrm{LD}_{50}$ results, these threats warrant the immediate upgrading of endosulfan to WHO Class I b [6].

Emblica officinalis (Amla) also known as Indian gooseberry is perhaps the most important medicinal plant in the Indian traditional system of medicine [7,8]. Amla is a source of phenolic compounds, which include phenolic acids and flavonoids [9]. Apart from vitamin $\mathrm{C}$, amla also contains cytokine like substances such as zeatin. The dried Amla fruit is useful in the treatment of hemorrhage, diarrhea, dysentery and is the best antioxidant known in India [10]. Hence, the present work aims to study the ameliorative effect against Endosulfan induced toxicity in Swiss albino mice.

\section{Materials and Methods}

\section{Ethical approval}

Ethical approval was taken from Post Graduate Research Council (PGRC) of Patna University, Patna with no. PGRC No. Acad - / 464, serial No. 7, dated 12/02/2007. 


\section{Animals}

Twenty four Swiss albino mice $(28 \mathrm{~g}$ to $32 \mathrm{~g}$ ) were obtained from animal laboratory of Dr. A. Nath, Department of Zoology, Patna University and Patna, India. The research work was approved by the Post Graduate Research Council of the Patna University. Food and water to mice were provided ad libitum (prepared mixed formulated feed by the laboratory itself). Animals were maintained in colony rooms with $12 \mathrm{hrs} \mathrm{light/dark} \mathrm{cycle} \mathrm{at} 22 \pm 2^{\circ} \mathrm{C}$.

\section{Chemicals}

The commonly used pesticide- endosulfan was obtained (Excel India Pvt. Ltd. Mumbai with EC 35\%). The pesticide was prepared to $3 \mathrm{mg} / \mathrm{Kg}$ b.w, which was administered orally to mice for 4 weeks. Commercially available kit for chemical analyses like Serum Cholesterol, HDL, LDL Cholesterols and Triglyceride were used of crest coral clinical system, Goa, India.

\section{Plant material}

The fresh dried fruit form of Amla purchased from herbal store in Patna and identified by Dr. V Pandit, Department of Botany, Patna Science College, Patna University Patna, India and aqueous extract was made by dissolving it in distilled water using by mortal and pistal. The dose was finally made to $100 \mathrm{mg} / \mathrm{kg}$ body weight for oral administration.

\section{Experimental design}

In the present study 24 mice ( 18 Endosulfan treated and 6 as control mice) were taken and divided into groups - control, Endosulfan treated and Amla treated. The endosulfan at the rate of $3 \mathrm{mg} / \mathrm{kg}$ body weight daily was administered orally for 4 weeks. To this endosulfan treated group amla at the rate of $100 \mathrm{mg} / \mathrm{kg}$ body weight was administered for 4 weeks. After the completion of the experiment blood samples were collected by orbital sinus puncture method and then serum was extracted.

\section{Statistical analysis}

Results are presented as mean \pm S.D and total variation present in a set of data was analyzed through one-way analysis of variance (ANOVA). Difference among means has been analyzed by applying Dunnet's ' $\mathrm{t}$ ' test at $99.9 \%(p<0.001)$ confidence level. Calculations were performed with the GraphPad Prism Program (GraphPad Software, Inc., San Diego, USA).

\section{Results}

The lipid profile tests total cholesterol levels, LDL cholesterol levels and triglycerides levels show inclination in the levels while HDL cholesterol decreased levels in the Endosulfan treated group in comparison to control group was observed. But, after E.officinalis treatment total cholesterol levels, LDL cholesterol levels and triglycerides levels shows decreased in the levels while there was significant increase in the HDL cholesterol levels denotes the ameliorative effects (Figures 1-4)
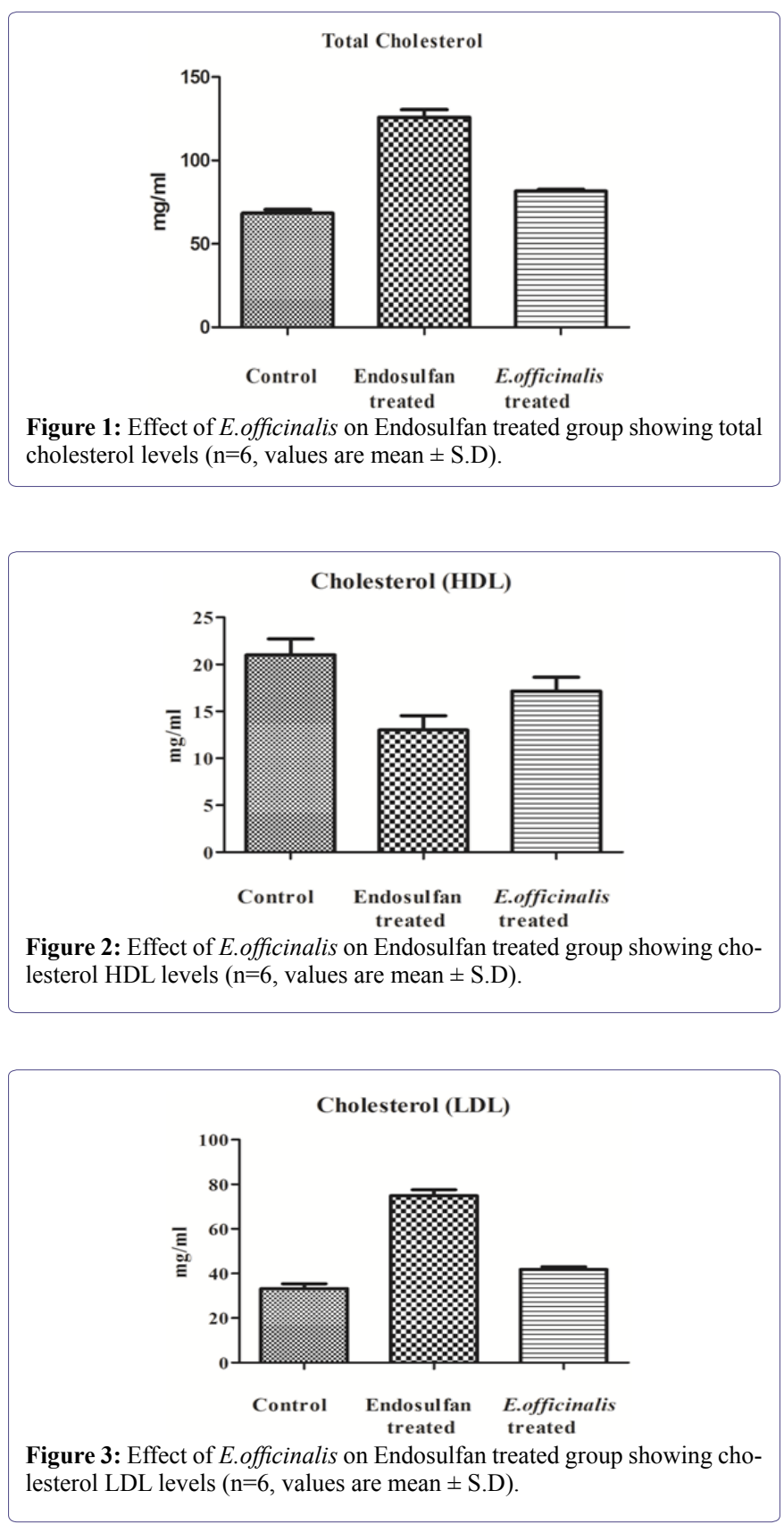
glycerides levels $(\mathrm{n}=6$, values are mean \pm S.D)
glinalis on Endosulfan 


\section{Discussion}

Lipids are one of the important sources of energy, carriers of fat-soluble vitamins, components of bile salts and precursors for the synthesis of steroid hormones. Lipids are mainly synthesized in liver. Biochemical characteristics of blood are the important indicator of status of internal environment of an organism. Most of the pesticides act as metabolic depressors and generally affect the activity of biologically active molecules such as proteins, carbohydrates and lipids [11]. A number of studies have been carried out regarding the biochemical alterations in blood induced by pesticides in general [1218].

In the present study, the hyperlipidaemia in mice exposed to endosulfan can reasonably explained on the basis of hypothesis that endosulfan induces oxidative stress in the cells especially in hepatocytes. Liver is the main site of detoxification so it requires more energy for detoxification. To meet additional energy demands liver cells starts biosynthesizing of different classes of lipids. This leads to the elevation in total cholesterol, LDL cholesterol, and triglyceride level in blood serum of endosulfan induced mice. Hence, it can be speculated that inclination in lipid profile is one of the compensatory mechanism of mice to adopt to pesticides like endosulfan. The inclination in serum lipid content resulting in hyperlipidaemia is certainly due to stress induced by pesticide poisoning for longer periods. The test animals in the present study were observed to be restless throughout the exposure period. They were in constant fast movements aided by muscular action. Lots of extra energy was required to minimize the stress induced by endosulfan. The observed hyperlipidaemia during present investigation may be also due to impairment in the membrane organization and damage to liver. In a similar study, [19] have reported that increased level of serum cholesterol in Oreochromis niloticus exposed to phenol may be due to impairment in the membrane organization induced by the acclimatization in acidic water or water contaminated with phenol in order to get the positive survival value under the imposed stress. Endosulfan, are also known to induce oxidative tissue damage resulting from the release of ROS [20] and free radicals play an important role in the pathogenesis of inflammation [20-23]. Endosulfan also acts as a xenoestrogen binding with the lipid membranes and causing severe damage to them due to lipid peroxidation. The lipid peroxidation in turn causes depletion of lipid from the membranes making the blood lipid rich, more viscous and enhancing the chance cardiovascular disease. Thus, there are multiple possible pathways that might lead to selective alteration in rates of synthesis or metabolism of some classes of serum lipids. Lipid profile abnormalities play a significant role in atherosclerosis and cardiovascular disease. The findings of the present investigation indicate that exposure to endosulfan alters the metabolism of cholesterol and thus increases the risk of cardiovascular disease and atherosclerosis.

But, the medicinal plants have potent ameliorative effect in controlling the hyperlipidaemic effect. The high levels of vitamin $\mathrm{C}$ and fiber in amla are thought to be responsible for its cholesterol-lowering effects. Amla reduced levels of triglycerides (TG) TG in the blood. High TG level of in the blood are linked to low levels of High-Density Lipoprotein-Cholesterol (HDL-C) The vitamin C in amla accounts for $45-70 \%$ of its antioxidant activity. Reactive Oxygen and Nitrogen Species (ROS and RNS) cause inflammation. The phenolic compounds in amla decreases both ROS and RNS. Amla reduces oxidative stress in DNA and prevents liver cells from dying (necrosis) [24].
In the present study also there was significant amelioration in the lipid profile levels denotes that Amla indeed possesses antihyperlipidaemic property. The phenolic compounds of E.officinalis may serve as potential medicinal plant for amelioration of acute and chronic inflammation due to their modulatory action of free radicals [25]. The pharmacological studies have also shown that amla fruit was able to lower the lipid level in the liver of rodents [26]. Other studies also reveal that free phenolic contents of E.officinalis were three times more than that of bound form. Both phenolic fractions of E.officinalis are consisting of gallic and tannic acid. Phenolic fractions are also known to possess various secondary metabolites, such as flavonoids and phenolic acids, etc., that are well known to possess highest antioxidant activity [27-32]. Hence, the present study reveals that Emblica officinalis possesses ameliorating property against endosulfan induced toxicity.

\section{Conclusion}

Endosulfan causes deleterious effect on the lipid profile functions in the Swiss albino mice, but after the treatment of Emblica officinalis there was significant control in the lipid profile levels. Thus, Emblica officinalis possesses anti-hyperlipidaemic activity normalizing the physiology of the body and maintaining the cellular integrity and normal functioning of the system.

\section{Acknowledgement}

The authors are thankful to the Department of Zoology, Patna University for the infrastructural facilities. Conflict of interest: The authors declare that they have no conflict of interests.

\section{References}

1. Rajendran S (2003) Environment and health aspects of pesticides use In Indian agriculture. In: Bunch MJ, Suresh MV, Kumaran TV (Eds.), Proceedings of the third international conference on environment and health, Chennai, India. Pg no: 353-373.

2. Pimentel D (1995) 2 pesticides reaching target pests: Environmental impacts and ethics. J Agric Environ Ethics 8: 17-22.

3. ATSDR (2000) Toxicological profile for endosulfan. Agency of Toxic Substances and Disease Registry, USA.

4. Helle RA, Marie VA, Thomas HR, Marianne GI, Eva CBJ (2002) Effects of currently used pesticides in assays for estrogenicity and rogenicit and aromatase activity in vitro. Toxicology and Applied Pharmacology. 179: $1-12$.

5. WHO (2005) The WHO recommended classification of pesticides by hazard. World Health Organization, Geneva, Switzerland.

6. EPA (2002) Reregistration eligibility decision for Endosulfan. United States Environmental Protection Agency, Washington, D.C., USA.

7. Krishnaveni M, Mirunalini S (2010) Therapeutic potential of Phyllanthus emblica (amla): The ayurvedic wonder. J Basic Clin Physiol Pharmacol 21: 93-105.

8. Satyavati GV, Raina MK, Sharma M (1976) Medicinal plants of India. Indian Council of Medical Research, New Delhi, India.

9. Kumar SG, Harish N, Dharmesh SM, Salimath V (2006) Free and bound phenolic antioxidants in amla (Emblica officinalis) and turmeric (Curcuma longa). J Food Comp Anal 19: 446-452.

10. Liu X, Cui C, Zhao M, Wang J, Luo W, et al. (2008) Identification of phenolics in the fruit of emblica (Phyllanthus emblica L.) and their antioxidant activities. Food Chem 109: 909-915. 
11. Agrahari S, Gopal K (2009) Fluctuations of certain biochemical constituents and markers enzymes as a consequence of monocrotophos toxicity in the edible freshwater fish, Channa punctatus. Pest Biochem. Physiol 94: 5-9.

12. Pant J, Singh T (1983) Induction of metabolic dysfunction by carbamate and organ phosphorus compounds in a fish, Puntius conchonius. Pestic Biochem Physiol 20: 294-298.

13. Bhushan PB, Singh MK, Rani M (2002). Dimethoate and monocil toxicity on concentration of protein and amino acid in serum and liver of Channa punctatus. Nat Environ Poll Technol 1: 147-150.

14. Mohamed FAS, Gad NS (2008) Environmental pollution-induced biochemical changes in tissues of Tilapia zillii, Solea vulgaris and Mugil capito from Lake Qarun, Egypt. Glob Veterin 2: 327-336.

15. Jenkins JC, Chojnacky DC, Heath LS, Birdsey RA (2003) National-scale biomass estimation for United States tree species. For Sci 49: 12-35.

16. Rajamanickam V, Muthuswamy N (2008) Effect of heavy metals induced toxicity on metabolic biomarkers in common carp ( Cyprinus Carpio L.) Maejo Intern J Sci Technol 2: 192-200.

17. Saravanan VS, Kumar MR, Sa TM (2011) Microbial zinc solubilization and their role on plants. In: Maheshwari DK (Ed.), Bacteria in Agrobiology: Plant nutrient management. Springer, Berlin, Germany. Pg no: 47-63.

18. Yekeen TA, Fawole OO (2011) Toxic effects of endosulfan on haematological and biochemical indices of Clarias gariepinus. Afr J Biotechnol 10: $14090-14096$

19. Gad NS, Saad AS (2008) Effect of environmental pollution by phenol on some physiological parameters of Oreochromis niloticus. Glob Veterin 2: 312-319.

20. Hincal F, Gürbay A, Giray B (1995) Induction of lipid peroxidation and alteration of glutathione redox status by endosulfan. Biol Trace Elem Res 47: 321-326.

21. Di Rosa M, Giroud JP, Willoughby DA (1971) Studies on the mediator of the acute inflammatory response induced in rats in different sites by carrageenan and turpentine. J Pathol 104: 15-29.
22. Koblyakov VA (2001) Free radicals and inflammation. In: Winyard P, Blake DR, Evans CH (Eds.), progress in inflammation research series. Biochemistry, Springer, Berlin, Germany 66: 937-938.

23. Sood S, Arora B, Bansal S, Muthuraman A, Gill NS, et al. (2009) Antioxidant, anti-inflammatory and analgesic potential of the Citrus decumana L. peel extract. Inflammopharmacol 17: 267-274.

24. Maiti S, Chattopadhyay S, Acharyya N, Deb B, Hati AK (2014) Emblica officinalis (amla) ameliorates arsenic-induced liver damage via DNA protection by antioxidant systems. Mol Cell Toxicol 10: 75-82.

25. Perry LM, Metzger J (1980) Medicinal plants of east and Southeast Asia: Attributed properties and uses. MIT Press, Cambridge, Massachusetts, USA. Pg no: 195-196.

26. Deokar AB (1998) Medicinal plants grown at Rajegaon. Vikas Foundation, Pune India. Pg no: 48-49.

27. Arumugam P, Ramamurthy P, Santhiya ST, Ramesh A (2006) Antioxidant activity measured in different solvent fractions obtained from Mentha spicata Linn: An analysis by ABTS*+ Decolorization assay. Asia Pac J Clin Nutr 15: 20-24.

28. Anila L, Vijayalakshmi NR (2002) Flavonoids from Emblica officinalis and Mangifera indica effectiveness for dyslipidemia. J Ethnopharmacol 79: 81 .

29. Vinson JA, Hao Y, Su X, Zubik L (1998) Phenol antioxidant quantity and quality in foods: Vegetables. J Agric Food Chem 46: 3630-3634.

30. Jung M, Park M, Lee HC, Kang YH, Kang ES, et al. (2006) Antidiabetic agents from medicinal plants. Curr Med Chem 13: 1203-1218.

31. Cuvelier ME, Richard H, Berset C (1992) Comparison of the antioxidative activity of some acid-phenols: Structure-activity relationship. Biosci Biotechnol Biochem 56: 324-325.

32. Subba Rao MVSST, Murlikrishna G (2002) Evaluation of the antioxidant properties of free and bound phenolic acid from native and malted finger millet (Ragi, Eleusine coracana Indaf- 15). J Agric Food Chem 50: 889892. 


\section{di \\ неram}

Advances In Industrial Biotechnology | ISSN: 2639-5665

Advances In Microbiology Research | ISSN: 2689-694X

Archives Of Surgery And Surgical Education | ISSN: 2689-3126

Archives Of Urology

Archives Of Zoological Studies | ISSN: 2640-7779

Current Trends Medical And Biological Engineering

International Journal Of Case Reports And Therapeutic Studies | ISSN: 2689-310X

Journal Of Addiction \& Addictive Disorders | ISSN: 2578-7276

Journal Of Agronomy \& Agricultural Science | ISSN: 2689-8292

Journal Of AIDS Clinical Research \& STDs | ISSN: 2572-7370

Journal Of Alcoholism Drug Abuse \& Substance Dependence | ISSN: 2572-9594

Journal Of Allergy Disorders \& Therapy | ISSN: 2470-749X

Journal Of Alternative Complementary \& Integrative Medicine | ISSN: 2470-7562

Journal Of Alzheimers \& Neurodegenerative Diseases | ISSN: 2572-9608

Journal Of Anesthesia \& Clinical Care | ISSN: 2378-8879

Journal Of Angiology \& Vascular Surgery | ISSN: 2572-7397

Journal Of Animal Research \& Veterinary Science | ISSN: 2639-3751

Journal Of Aquaculture \& Fisheries | ISSN: 2576-5523

Journal Of Atmospheric \& Earth Sciences | ISSN: 2689-8780

Journal Of Biotech Research \& Biochemistry

Journal Of Brain \& Neuroscience Research

Journal Of Cancer Biology \& Treatment | ISSN: 2470-7546

Journal Of Cardiology Study \& Research | ISSN: 2640-768X

Journal Of Cell Biology \& Cell Metabolism | ISSN: 2381-1943

Journal Of Clinical Dermatology \& Therapy | ISSN: 2378-8771

Journal Of Clinical Immunology \& Immunotherapy | ISSN: 2378-8844

Journal Of Clinical Studies \& Medical Case Reports | ISSN: 2378-8801

Journal Of Community Medicine \& Public Health Care | ISSN: 2381-1978

Journal Of Cytology \& Tissue Biology | ISSN: 2378-9107

Journal Of Dairy Research \& Technology | ISSN: 2688-9315

Journal Of Dentistry Oral Health \& Cosmesis | ISSN: 2473-6783

Journal Of Diabetes \& Metabolic Disorders | ISSN: 2381-201X

Journal Of Emergency Medicine Trauma \& Surgical Care | ISSN: 2378-8798

Journal Of Environmental Science Current Research | ISSN: 2643-5020

Journal Of Food Science \& Nutrition | ISSN: 2470-1076

Journal Of Forensic Legal \& Investigative Sciences | ISSN: 2473-733X

Journal Of Gastroenterology \& Hepatology Research | ISSN: 2574-2566
Journal Of Genetics \& Genomic Sciences | ISSN: 2574-2485

Journal Of Gerontology \& Geriatric Medicine | ISSN: 2381-8662

Journal Of Hematology Blood Transfusion \& Disorders | ISSN: 2572-2999

Journal Of Hospice \& Palliative Medical Care

Journal Of Human Endocrinology | ISSN: 2572-9640

Journal Of Infectious \& Non Infectious Diseases | ISSN: 2381-8654

Journal Of Internal Medicine \& Primary Healthcare | ISSN: 2574-2493

Journal Of Light \& Laser Current Trends

Journal Of Medicine Study \& Research | ISSN: 2639-5657

Journal Of Modern Chemical Sciences

Journal Of Nanotechnology Nanomedicine \& Nanobiotechnology | ISSN: 2381-2044

Journal Of Neonatology \& Clinical Pediatrics | ISSN: 2378-878X

Journal Of Nephrology \& Renal Therapy | ISSN: 2473-7313

Journal Of Non Invasive Vascular Investigation | ISSN: 2572-7400

Journal Of Nuclear Medicine Radiology \& Radiation Therapy | ISSN: 2572-7419

Journal Of Obesity \& Weight Loss | ISSN: 2473-7372

Journal Of Ophthalmology \& Clinical Research | ISSN: 2378-8887

Journal Of Orthopedic Research \& Physiotherapy | ISSN: 2381-2052

Journal Of Otolaryngology Head \& Neck Surgery | ISSN: 2573-010X

Journal Of Pathology Clinical \& Medical Research

Journal Of Pharmacology Pharmaceutics \& Pharmacovigilance | ISSN: 2639-5649

Journal Of Physical Medicine Rehabilitation \& Disabilities | ISSN: 2381-8670

Journal Of Plant Science Current Research | ISSN: 2639-3743

Journal Of Practical \& Professional Nursing | ISSN: 2639-5681

Journal Of Protein Research \& Bioinformatics

Journal Of Psychiatry Depression \& Anxiety | ISSN: 2573-0150

Journal Of Pulmonary Medicine \& Respiratory Research | ISSN: 2573-0177

Journal Of Reproductive Medicine Gynaecology \& Obstetrics | ISSN: 2574-2574

Journal Of Stem Cells Research Development \& Therapy | ISSN: 2381-2060

Journal Of Surgery Current Trends \& Innovations | ISSN: 2578-7284

Journal Of Toxicology Current Research | ISSN: 2639-3735

Journal Of Translational Science And Research

Journal Of Vaccines Research \& Vaccination | ISSN: 2573-0193

Journal Of Virology \& Antivirals

Sports Medicine And Injury Care Journal | ISSN: 2689-8829

Trends In Anatomy \& Physiology | ISSN: 2640-7752

Submit Your Manuscript: https://www.heraldopenaccess.us/submit-manuscript 